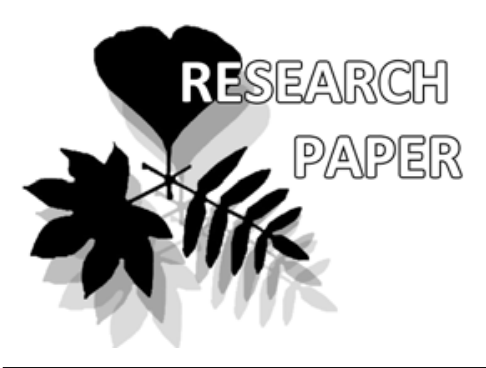

Lyudmila M. Pshennikova

e-mail: pshennikova1@yandex.ru

Botanical Garden-Institute FEB RAS, Vladivostok 690024 Russia

Manuscript received: 25.12 .2015

Review completed: 28.03.2016

Accepted for publication: 06.04.2016

Published online: 31.05.2016

\section{Achene morphology of the Far Eastern species of the genus Dasiphora Raf. (Rosaceae): Systematic implications}

\author{
Lyudmila M. Pshennikova
}

\begin{abstract}
A B S T R A C T
This paper presents results of morphological comparison between five Far Eastern taxa in the genus Dasiphora. Such morphological characteristics as size and pubescence of achenes show significant difference of $D$. davurica var. flava from other Far Eastern taxa of this genus. These data and our previous studies demonstrate taxonomic peculiarities of the $D$. davurica var. flava and bring to the idea of its consideration at the level of species. The new nomenclatural combination Dasiphora flava: (Vorosch.) Gorovoj, Pshenn. et S. Volkova is proposed.

Ke ywords : Dasiphora, Potentilla, Pentaphylloides, the Russian Far East, morphology, achene, taxa

\section{P E 3 Ю M E}

Пшенникова И.М. Морфология орешков дальневосточных видов роa a Dasiphora Rafin (Rosaceae): систематическое значение. Приведены результаты морфологических исследований орешков пяти таксонов Аальневосточных представителей рода Dasiphora. Показано, что таксон $D$. davurica var. flava размерами орешков и их опушением значительно отличается от Аругих Аальневосточных представителей рода. Полученные данные указывают на необходимость придания разновидности $D$. davurica var. flava статуса вида. Приводится новая номенклатурная комбинация Dasiphora flava (Vorosch.) Gorovoj, Pshenn. et S. Volkova.

Км чоевы е смова: Dasiphora, Potentilla, Pentaphylloides, российский Аальний Восток, морфология, орешек, таксон
\end{abstract}

Plants of the genus Dasiphora belong to shrubs. Representatives of this genus are also considered as Pentaphylloides Duham (Yakubov 1996, Koropachinskiy \& Vstovskaya 2002) or Potentilla L. (Voroshilov 1982, 1985, Kamelin 2001). In recent floristic summaries (Kozhevnikov \& Probatova 2006, Baikov 2012) the shrubby potentillas were treated under the name Dasiphora Rafin. The genus Dasiphora, family Rosaceae includes 10 species distributed in Europe, Asia and North America (Shipchinsky 1954). Species of the genus are well known for their ornamental and medicinal properties (Triel \& Sokolenko 2010). The genus Dasiphora is represented in the Russian Far East by 5 taxa: D. davurica (Nestl.) Kom. et Alis., D. mandshurica (Maxim.) Juz., D. fruticosa (L.) Rydb. (Probatova \& Barkalov 2006), D. gorovoii Pshenn. (Pshennikova 2006) and D. davurica var. flava (Vorosch.) Gorovoj, Pshenn. et S. Volkova (Volkova et al. 2009). However, the systematic position of $D$. davurica var. flava remains unclear. Under the name Potentilla davurica Nestl. var. flava Vorosch. this plant was first identified and described from Olginsky district, Primorsky Krai by Voroshilov (1972) more than 40 years ago. Voroshilov (1972) noted that Potentilla davurica plants collected from this site have unusually dark-yellow flowers, small, bare and narrow leaflets with a slightly bluish color, so he described these plants as $P$. davurica var. flava Vorosch. Later, this author proposed a new combination for $P$. glabrata Willd - P. fruticosa L. subsp. glabrata (Willd.) Vorosch. and indicated P. davurica as its synonym (Voroshilov 1982, 1985).
To compare $D$. davurica var. flava from Olginsky district with other Far Eastern taxa of this genus, we studied its chromosome numbers and anatomical structure of leave epidermis and petioles (Volkova et al. 2009, Volkova \& Pshennikova 2011, Pshennikova \& Volkova 2013) and came to conclusion that this taxon can be the result of natural hybridization.

Morphological characteristics of seeds are important for classification of individual species into groups within genera (Belyaev 1984, Kovtonyuk 1994, Kozhanchikov 1967). Sculpture of achenes' surface and the presence of trichomes are important systematic features for the genus Potentilla. Since Dasiphora plants show high variability in this feature (Kurbatsky 1984, 2008), our objective was to identify taxonomic specialty and morphology of achenes of representatioves of the genus Dasiphora of the Russian Far East.

\section{MATERIAL AND METHODS}

We studied morphological features of achenes of 5 taxa from the genus Dasiphora using plants from living collections of the Botanical Garden-Institute FEB RAS (Vladivostok, Russia) that were grown under ecologically similar conditions. Plants of $D$. davurica, $D$. davurica var. flava, D. mandshurica, D. gorovoii, and D. fruticosa were transplanted from their natural habitat in the Russian Far East (Fig. 1). In living collection, $D$. fruticosa was represented by plants from two collection areas: Mt. Olkhovaya (1669 m), Sikhote-Alin Mountains, Primorsky Krai and upper reaches of 
Herbie river, Badzhalsky Mountain Range, Khabarovsky Krai. Achenes of each taxon were collected from 3-5 plants in October, 2013. A total of 50 achenes from each taxon were examined. We measured the length and maximum width of 10-12 achenes and also measured the length of trichomes. The structure of the achene surface was studied using a SEM EVO 40 (Carl Zeiss SMT) and a SM Stemi 2000-C (Carl Zeiss, Axiovision 4.8) microscopes. The data were processed using Statistica 9.0. The results are presented as mean values with standard errors. We used one-way ANOVA algorithm, consisted of following steps: 1) testing for normality (ShapiroWilk test); 2) testing the equality of variances (Bartlett's test) 3) applying standard parametric (Fisher's ANOVA) or non-parametric (KruskalWallis test) ANOVA procedure; 4) performing pairwise comparison of averages (Tukey test or Welch test with Bonferroni correction). All computations were performed with an aid of SciPy (Jones 2001-2016).

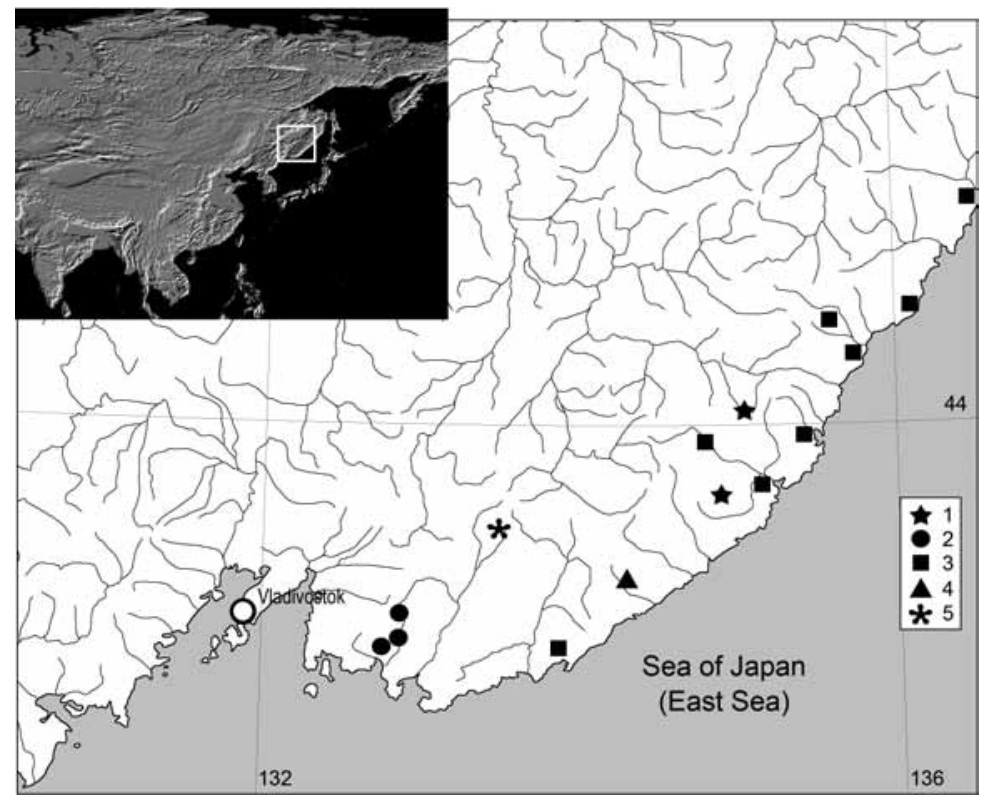

Figure 1 Location of sapmling sites of Dasiphora taxa in Primorsky Krai. $1-D$. davurica var. flava, $2-D$. davurica, 3 - D. mandshurica, 4 - D. gorovoii, 5 - D. fruticosa

\section{RESULTS AND DISCUSSION}

The achenes from five taxa were studied by SEM. This technique showed that the ultrastructures of the achenes of all studied species were formed by reticulate cells (Fig. 2).

\section{D. fruticosa}

According to our data, the achenes from both populations are similar. They vary from 1.24 to $1.71 \mathrm{~mm}$ in length (Table 1) and from 0.60 to $0.77 \mathrm{~mm}$ in width, have ovoid shape, mostly with slightly flattened sides, light brown to brown in colour, and densely villous. The villi consist of simple long trichomes, and the trichomes of plants from alpine populations are the longest compared with those of the other studied taxa (Table 1) and significantly longer $(0.5 \mathrm{~mm})$ than those of the eponymous species from Khabarovsky Krai. The middle part of the achene may be densely or sparsely villous. On achenes with pointed tops, there is a roundish scar. Two flat protuberances are noticeable on the ventral side. On the dorsal side they are rounder, narrowinging to form a scar. There are also short protuberances that appear as ledges of the pericarp. Our study coincides with published morphological features of achenes of D. fruticosa (Triel 1985, Triel \& Sokolenko 2010).

\section{D. mandshurica}

The morphological features were investigated for the first time. Achenes varied from 1.58 to $2.0 \mathrm{~mm}$ in length and from 0.65 to $0.91 \mathrm{~mm}$ in width, with an ovoid shape, mostly with slightly flattened sides, with a pointed apex, villous, almost yellow or light brown in colour. The villi consist of simple long trichomes and are evenly distributed on the surface. Two flat ptotuberances are noticeable on the ventral side, and the dorsal side is rounder, narrowing to form a scar. There are also short protuberances on the sides that appear as ledges of the pericarp. Achenes do not differ in form from the two types described above. Achenes of $D$. mandshurica are longer and wider than achenes of $D$. fruticosa, but its values are close to those of $D$. gorovoii (Table 1$)$. There is a statistically significant difference between lengths and widths of achenes from different species.

\section{D. gorovoii}

The morphological features of these achenes were studied for the first time. Achenes vary from 1.39 to $1.8 \mathrm{~mm}$ in length and from 0.60 to $0.91 \mathrm{~mm}$ in width, have an ovoid shape, mostly with slightly flattened sides, with a pointed apex, villous, and yellowish or light brown in color. The villi consist of simple long trichomes and are evenly distributed on the surface. Two flat protuberances are noticeable on the ventral side; the dorsal side is rounder, narrowing to form a scar. There are also short protuberances on the sides that appear as ledges of the pericarp. Achenes do not differ in form or colour from those of D. mandshurica, but are smaller in size (Table 1). There is a statistically significant difference between lengths and widths of achenes of $D$. mandshurica and D. gorovoii.

Table 1. Morphometric characteristics of Dasiphora achenes

\begin{tabular}{lccc}
\hline Taxon (specimen) & Length, $\mathbf{~ m m}$ & Width, $\mathbf{m m}$ & Length of trichomes, mm \\
\hline D. davurica & $1.54 \pm 0.28$ & $0.71 \pm 0.14$ & $1.25 \pm 0.32$ \\
D. davurica var. flava & $2.19 \pm 0.35$ & $1.09 \pm 0.04$ & $1.33 \pm 0.06$ \\
D. mandshurica & $1.81 \pm 0.05$ & $0.80 \pm 0.03$ & $1.36 \pm 0.04$ \\
D. gorovoii & $1.52 \pm 0.03$ & $0.73 \pm 0.002$ & $1.41 \pm 0.04$ \\
D. fruticosa (Mt. Olkhovaya) & $1.50 \pm 0.04$ & $0.76 \pm 0.01$ & $1.56 \pm 0.05$ \\
D. fruticosa (Khabarovsk) & $1.52 \pm 0.06$ & $0.64 \pm 0.02$ & $1.08 \pm 0.03$ \\
\hline
\end{tabular}

\section{D. davurica}

Achenes vary from 1.35 to $1.7 \mathrm{~mm}$ in length and from 0.62 to $0.77 \mathrm{~mm}$ in width, with an ovoid shape, primarily with slightly flattened sides, with a pointed apex, villous, yellowish 

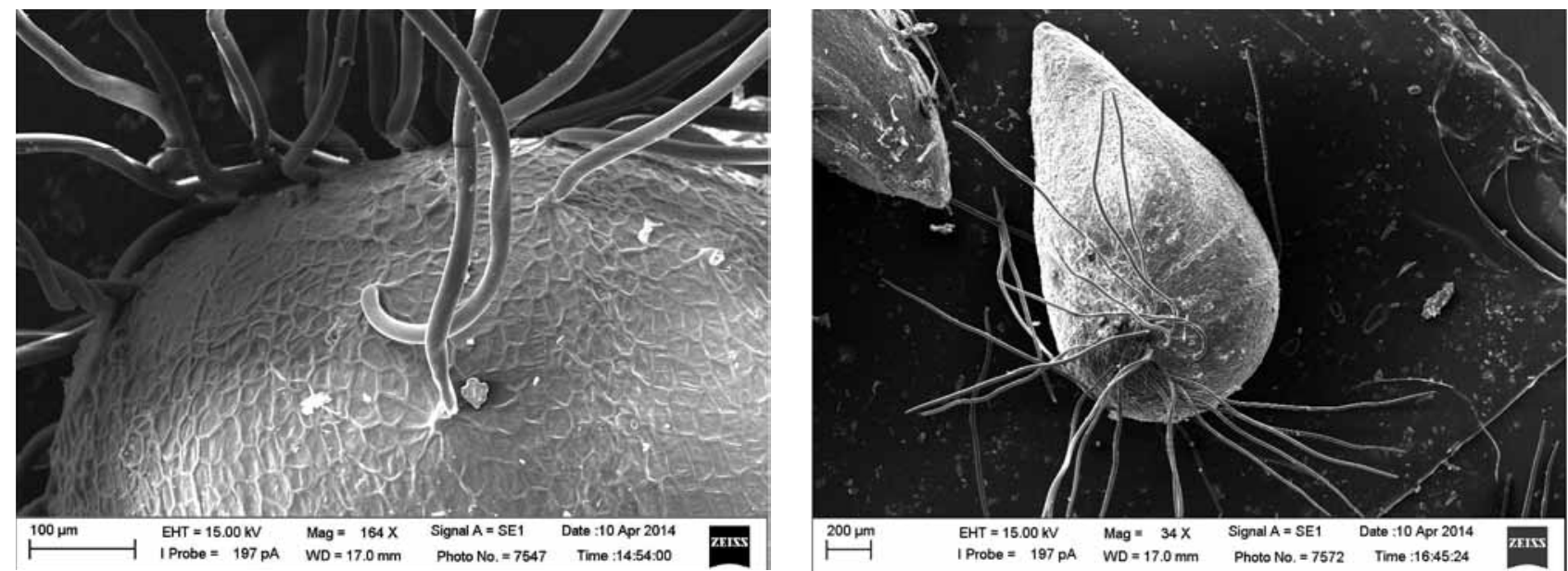

Figure 2 SEM micrographs of the surface of an achene of Dasiphora davurica var. flava. Sculpture of achene's surface is on the left and general view of achene on the right images

or light brown in colour. The villi consist of simple long hairs or trichomes and are concentrated primarily around the scar at the base of the achene and at the top. The middle part of the achene may be villous, rarely covered with villi or sometimes naked. Achenes with pointed tops have roundish scar. Two protuberances are noticeable on the flatter ventral side, narrowing to form a scar on the rounder dorsal side. There are also short protuberances on the sides that appear as ledges of the pericarp.

\section{D. davurica var. flava}

The morphological features of achenes were studied for the first time, revealing a fairly clear distinction between this taxon and the other studied species. The achenes vary from 2.04 to $2.35 \mathrm{~mm}$ in length and from 0.9 to $1.41 \mathrm{~mm}$ in width. They are larger, almost yellow or light brown in colour, ovoid or pear-shaped, with villi concentrated at the achene's base, the rest of the achene is naked (Figs. 2 and 3). It is believed that immature achenes exhibit denser villi
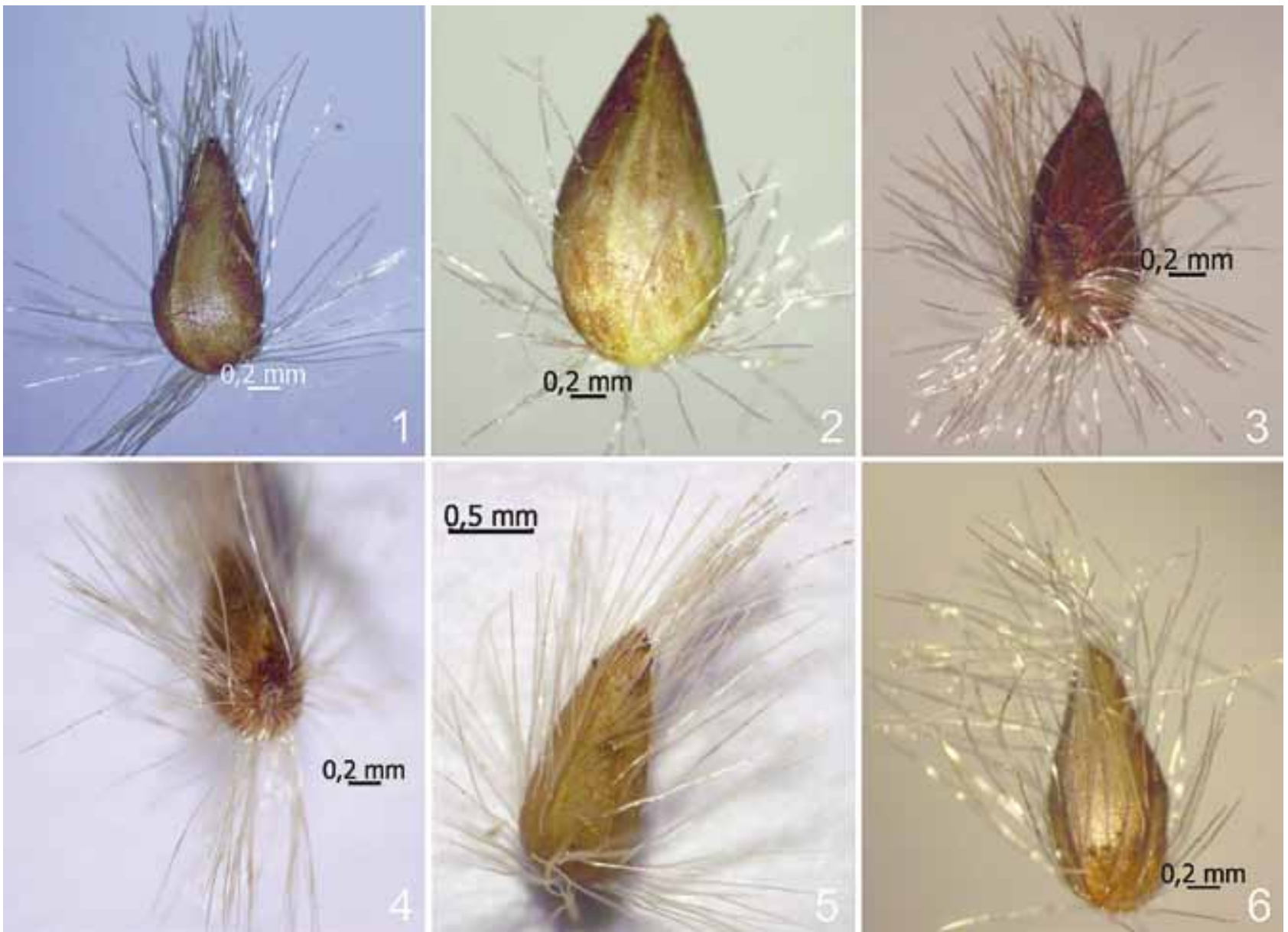

Figure 3 General view of the achenes of Dasiphora. $1-D$. davurica, $2-D$. davurica var. flava, 3 - D. fruticosa (Khabarovsk population), $4-$ D. fruticosa (Mt. Olkhovaya population), $5-$ D. gorovoii, $6-$ D. mandshurica 
coverage (Trill 1985, Trill \& Sokolenko 2010); therefore, we compared both immature and mature achenes. Villi in this taxon is the same in both phases.

\section{Taxonomically significant characters}

The results of studying achenes' length applying the one-way ANOVA algorithm are following:

- sample distribution is normal: D. fruticosa (Shapiro-Wilk test, $\mathrm{p}=0.699) ; D$. davurica $(\mathrm{p}=0.607) ; D$. davurica var. flava $(\mathrm{p}=0.037)$;

- Bartlett's test shows that sample variances could be treated as equal $(\mathrm{p}=0.824)$.

Therefore classical one-way ANOVA was performed. One-way ANOVA (Fisher's ANOVA) showed significant differences between groups $(p<0.001)$. So, next step is to uncover these differences by using pairwise comparison (Tukey's test). Applying Tukey's test with two levels of significance ( $\alpha=0.01$ and $\alpha=0.05$ ) leaded to following (at both levels): $D$. davurica and $D$. fruticosa do not differ significantly; pairs $D$. davurica and $D$. davurica var. flava and $D$. davurica var. flava and D. fruticosa are significantly different (Fig. 4).

The results of studying achenes' width by the same procedure are:

- data normality: $D$. fruticosa $(\mathrm{p}=0.142) ; D$. davurica $(\mathrm{p}=$ $0.107) ; D$. davurica var. flava $(\mathrm{p}=0.450)$;

- Bartlett's test to the data shows that samples have unequal variances $(\mathrm{p}<0.001)$.

Thus we used non-parametric one-way ANOVA to handle this case correctly. Using Kruskal-Wallis test yields to significant differences between groups $(p<0.001)$. Due to unequal variances we used Welch's test with Bonferroni correction to make parwise comparison of averages in this case. From this computational step we got the following (at the levels of significance $\alpha=0.01$ and $\alpha=0.05$ ) (Fig. 4): $D$. davurica and $D$. fruticosa do not differ significantly; pairs $D$. davurica vs $D$. davurica var. flava and $D$. davurica var. flava vs D. fruticosa are significantly different.

According to our recent observations, important peculiarity of $D$. davurica var. flava is tomentose inner side of

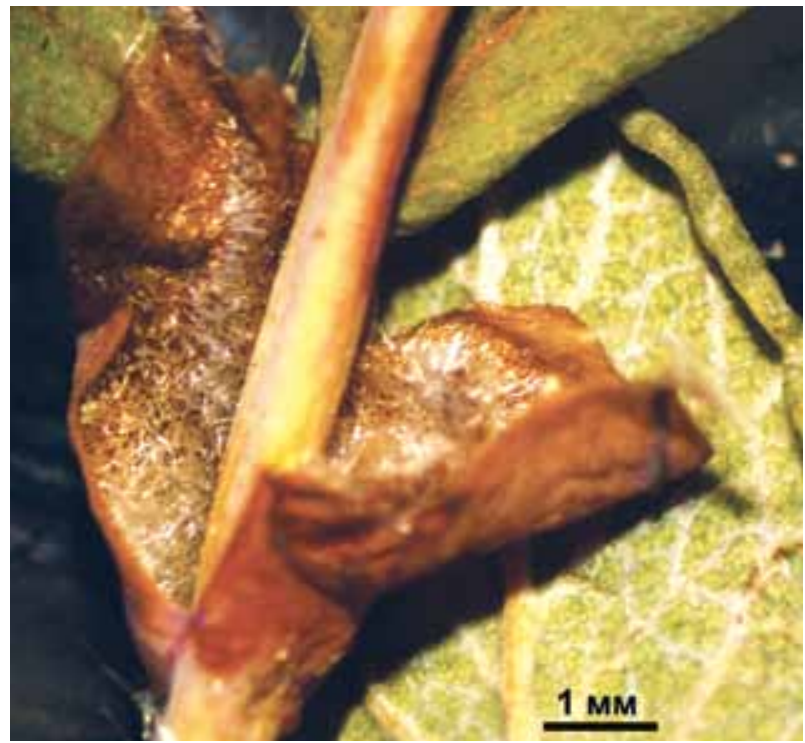

Figure 5 The inner side of the stipules $D$. davurica var. flava
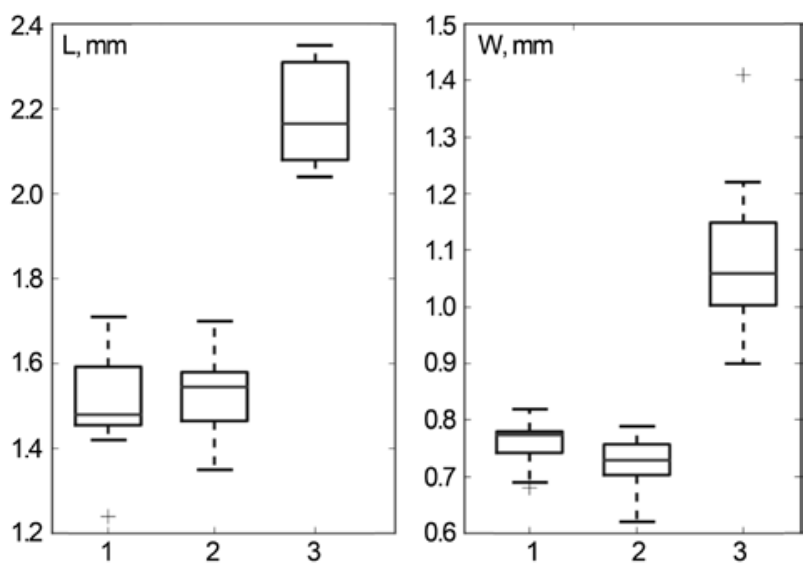

Figure 4 Box plots showing the differences of achene length (left) and width (right) for taxa $1-D$. fruticosa, $2-D$. davurica, $3-D$. davurica var. flava

the stipules, which is not typical for other four taxa from this genus (Fig. 5, 6). This variety combines morphological characteristics from both $D$. fruticosa and $D$. davurica. $D$. davurica var. flava has the same number of chromosomes $(2 \mathrm{n}=$ 14) as D. fruticosa (Volkova et al. 2009). Both D. davurica var. davurica and $D$. davurica var. flava have common features in the structure of epidermis (Volkova \& Pshennikova 2011). Three taxa, D. fruticosa, D. davurica var. davurica and $D$. davu-

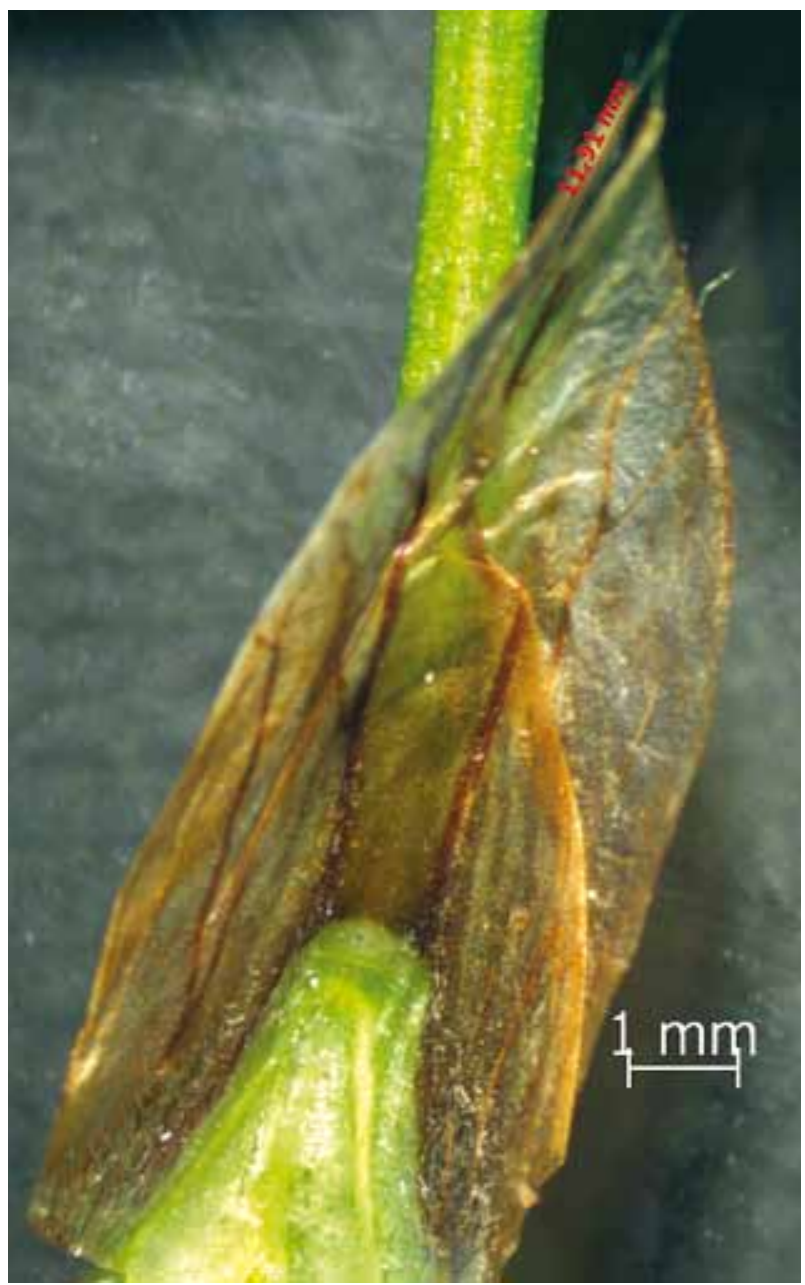

Figure 6 The inner side of the stipules $D$. davurica 
rica var. flava, have common features in anatomical structure of the petioles: single-rowed collenchyma occasionally turning into distich in adaxial protuberances and in the central part of abaxial side (Pshennikova \& Volkova 2013). Since D. davurica var. flava has common features with both $D$. davurica var. davurica and D. fruticosa, we can assume that this taxon is the result of natural hybridization.

Morphometric studies of achenes of the five Far Eastern taxa from the genus Dasiphora revealed that the general shape of a mature achene is quite steady. The achenes have unified structure and many common features indicating the evolutionary closeness of these taxa. The only significant differences that were identified separate $D$. davurica var. flava from other Far Eastern species of the genus. The main morphological distinctive properties of achenes are their size, trichome length, and location of villi on its surface. These data confirm the results of our previous study (Volkova et al. 2009, Volkova \& Pshennikova 2011, Pshennikova \& Volkova 2013) showing the taxon $D$. davurica var. flava merits species rank. Therefore the new combination is proposed: Dasiphora flava (Vorosch.) Gorovoj, Pshenn. et S. Volkova comb. et stat. nov. (Potentilla davurica Nestl. var. flava Vorosch. 1972, in Byull. Glavn. Bot. Sada (Moscow) 83: 36). Holotype: Russia, prov. Primorskensis, distr. Olga, prope pagum Novo-Nikolajevka, monticulus cretaceous, 27. IX 1969, V.N. Voroshilov (MHA) (Fig. 7).

\section{ACKNOWLEDGEMENTS}

The author is sincerely grateful to Dr. D.E. Kislov for the help with statistical analysis and E.A. Petrunenko (both - Botanical GardenInstitute FEB RAS, Vladivostok) for valuable help with English translation of this paper.

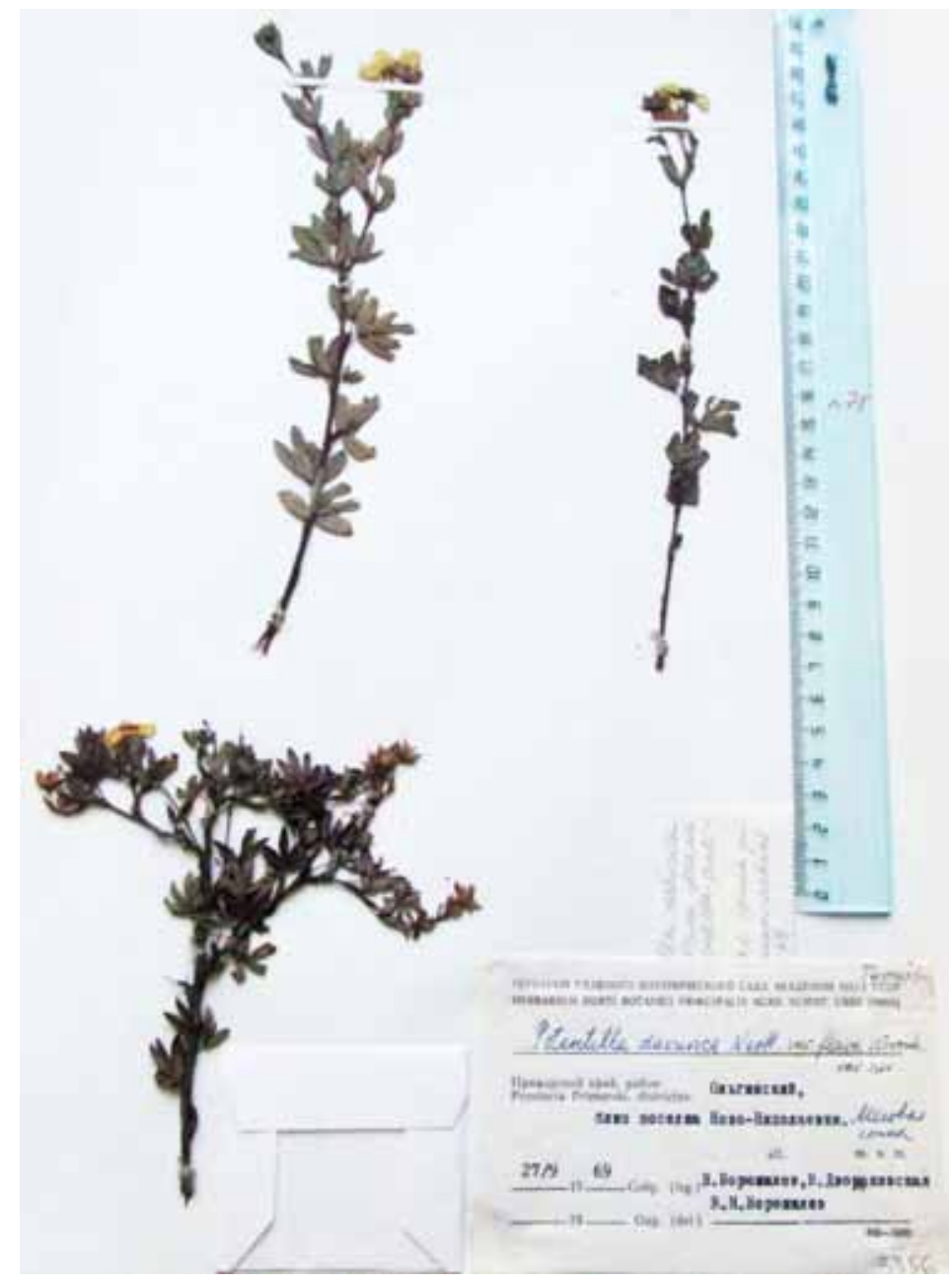

Figure 7 Type specimen (Typus) of Potentilla davurica var. flava (MHA)

\section{LITERAT URE CITED}

Baikov, K.S. (ed.) 2012. Conspectus florae Rossiae Asiaticae: Plantae vasculares. Izdatel'stvo SO RAN, Novosibirsk, 640 pp. (in Russian). [Конспект флоры Азиатской России: Сосудистые растения 2012. /под реА. К.С. Байкова. Новосибирск: ИзА-во СО РАН. 218 с.].

Belyaev, A.A. 1984. Surface ultrastructure and some morphological characteristics of seeds in the representatives of the family Campanulaceae. Botanichskii Zhurnal 69(7):890899 (in Russian). [Беляев А.А. 1984. УАьтраструктура поверхности и некоторые морфологические характеристики семян представителей семейства Campanulaсеае / / Бот. журн. Т. 69, № 7. С. 890-899].

Jones, E., E. Oliphant, P. Peterson et al. 2001-2016. SciPy: Open Source Scientific Tools for Python, http://www.scipy.org [online; last accessed 03.03.2016).

Kamelin, R.V. 2001. Potentilla L. In: Flora Europae orientalis. Magnoliophyta (= Angiospermae) Magnoliopsida (=Dicotyledones). (N.N. Tsvelev, eds.), Vol. 10, pp. 394-452. Mir i Sem'ya, Saint-Petersburg (in Russian). [Камелин P.B. 2001. РоА Potentilla L. // ФАора Восточной Европы. Покрытосеменные. Авудольные / под ред. Н.Н. Цвелёва. СанктПетербург: Мир и Семья. Т. 10. С. 394-452].
Koropachinskiy, I.Yu. \& T.N. Vstovskaya 2002. Woody plants of the Asian Part of Russia. "Geo", Novosibirsk, 707 pp. (in Russian). [Коропачинский И.Ю., Встовская T.Н. 2002. Аревесные растения Азиатской России. Новосибирск: «Гео», 707 с.].

Kovtonyuk, N.K. 1994. The structure of seed surface and the systematics of the Siberian Gypsophila (Caryophyllaceae). Botanichskii Zhurnal 79(4): 4-53 (in Russian). [Ковтонюк Н.К. 1994. Структура поверхности семян сибирских Gypsophila (Caryophyllaceae) в связи с систематикой // Бот. журн. Т. 79, № 4. С. 48-53].

Kozhanchikov, C.I. 1967. Morphological characteristics of seeds of the family Caryophyllaceae and possible ways of their evolution. Botanichskii Zhurnal 52(9): 1277-1286 (in Russian). [Кожанчиков В.И. 1967. Морфологические признаки семян семейства Caryophyllaceae и возможные пути их эволюции // Бот. журн. Т. 52, № 9. С. 1277-1286].

Kozhevnikov, A.E. \& N.S. Probatova (eds.) 2006. Flora of the Russian Far East. Addenda and corrigenda to "Vascularplants of the Soviet Far East", Vol.1-8 (1985-1996). Dalnauka, Vladivostok, 165 pp. (in Russian). [ФАора российского АаАь- 
него Востока. Аополнения и изменения к изданию «Сосудистые растения советского АаАьнего Востока» / отв. ред. А.Е. Кожевников и Н.С. Пробатова. Т. 1-8 (1985-1996). 2006. ВАадивосток: Аальнаука. 456 с.].

Kurbatski, V.I. 1984. The genus Potentuilla L. in the mountains of South Siberia: PhD thesis Abstract Biol. Sciences. Tomsk, 18 pp. (in Russian). [Курбатский В.И. 1984. Род Potentilla L. в горах Южной Сибири: Автореф. Аис. ... канА. биол. наук. Томск. 18 с.].

Kurbatski, V.I. 2008. On intrapartum systematics of Potentilla L. and Comarum L. s.l. Sistematicheskie zametki po materialam gerbariya im. P.N. Krylova pri Tomskom gosudarstvennom universitete 99: 1-7 (in Russian). [Курбатский В.И. 2008. K внутриродовой систематике Potentilla L. и Comarum L. s.l. // Систематические заметки по материалам Гербария им. П.Н. Крылова при Томском гос. ун-те. № 99. C. 1-7].

Probatova, N.S. \& V.Yu. Barkalov 2006. Dasiphora Raf. In: Flora of the Russian Far East. Addenda and corrigenda to "Vascular plants of the Soviet Far East", Vol. 1-8 (1985-1996). (Kozhevnikov, A.E. \& N.S. Probatova, eds.), p. 165. Dalnauka, Vladivostok (in Russian). [Пробатова H.C., Бар-

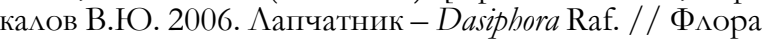
российского АаАьнего Востока. Аополнения и изменения к изданию «Сосудистые растения советского Аальнего Востока». Т. 1-8 (1985-1996). ВАадивосток: Аальнаука. С. 165].

Pshennikova, L.M. 2006. A new species of the genus Dasiphora (Rosaceae) from the Russian Far East. Botanichskit Zhurnal 91(6):951-954 (in Russian). [Пшенникова А.M. 2006. Новый вих рода Dasiphora (Rosaceae) с Аальнего Востока России // Бот. журн. Т. 91, № 6. С. 951954].

Pshennikova, L.M., S.A. Volkova 2013. Anatomical structure of the leaf petioles in species of Dasiphora (Rosaceae). Turczaninowia 16(2):106-109 (in Russian). [Пшенникова А.М., Волкова С.А. 2013. Анатомическое строение черешков листьев видов рода Dasiphora (Rosaceae) // Turczaninowia. T. 16, № 2. C. 106-109].

Shipchinsky N.V. 1954. Dasiphora Raf. In: Trees and Shrubs of the USSR. Vol. 3 (S.Ya. Sokolov, ed.), pp. 611-614, Izdatel'stvo AN SSSR, Moscow, Leningrad (in Russian). Шипчинский Н.B. 1954. Курильский чай - Dasiphora Raf. // Аеревья и кустарники СССР / под ред. С.Я. Соколова. Москва, Аенинград: ИзА-во АН СССР. Т. 3. C. 611-614].

Triel', V.M. 1985. Morphological features of seed of Pentaphylloides fruticosa (L.) Schwarz in different phytocenoses of mountain Altai. Rastitel'nye Resursy 4:450-452 (in Russian). [Триль B.M. 1985. Морфологические особенности семян Pentaphylloides fruticosa (L.) Schwarz в различных фитоценозах горного Алтая // Растительные ресурсы. Вып. 4. С. 450-452].

Triel', V.M, O.A. Sokolenko 2010. Shrubby cinquefoil in nature and in culture (reproductive biology). "Magarin O.G.", Maikop, 132 pp. (in Russian). [Триль B.М., Соколенко О.А. 2010. Курильский чай в природе и в культуре (репроАуктивная биология). Майкоп: «Магарин О.Г.» 132 c.].

Volkova, S.A., L.M. Pshennikova \& P.G. Gorovoi 2009. The chromosome numbers of species Dasiphora (Rosaceae) from the Russian Far East. Botanicheskii Zhurnal 94(6): 903-905 (in Russian). ВВокова C.А., Пшенникова А.М., Горовой П.Г. 2009. Числа хромосом видов рода Dasiphora (Rosaceae) российского Аальнего Востока / / Бот. журн. Т. 94, № 6. С. 903-905].

Volkova, S.A. \& L.M Pshennikova 2011. The leaf epidermis in species of genus Dasiphora (Rosaceae). Turczaninowia 14(2): 123-129 (in Russian). [Волкова С.А., Пшенни-

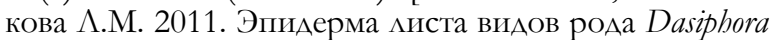
(Rosaceae) // Turczaninowia. T. 14, № 2. C. 123-129].

Voroshilov, V.N. 1972. New taxa of flora of the Far East. Byulleten' Glavnogo Botanicheskogo Sada 83: 34-38 (in Russian). [Ворошилов В.Н. 1972. Новые таксоны из флоры Аальнего Востока // Бюлц. Гцавн. Бот. сада. Вып. 83. C. 34-38].

Voroshilov, V.N. 1982. Opredelitel' rastenii sovetskogo Dal'nego Vostoka. Nauka, Moscow, pp. 343-351 (in Russian). [Boрошилов В.Н. 1982. Определитель растений советского АаАьнего Востока. Москва: Наука. С. 343-351].

Voroshilov, V.N. 1985. List of the vascular plants of the soviet Far East. In: Floristic studies in different regions of the USSR. Nauka, Moscow, pp. 139-200 (in Russian). [Boрошилов В.Н. 1985. Список сосудистых растений советского Аальнего Востока // Фцористические исследования в разных районах СССР. Москва: Наука. C. 139-200].

Yakubov, V.V. 1996. Pentaphylloides Duham. In: Plantae vasculares orientis extremi sovietici. Vol. 8 (S.S. Kharkevich, ed.), pp. 165-166, Nauka, Saint-Petersburg (in Russian). [Якубов B.B. 1996. Пятилисточник - Pentaphylloides Duham. // Сосудистые растения советского Аальнего Востока, Санкт-Петербург: Наука. Т. 8. С. 165-166]. 